\title{
Perception of Teacher on Cooperative Learning
}

\author{
Nur Salimah Alias*, Huzili Hussin, Junainor Hassan, Nor Syamimi Mohamed Adnan, Mohamad Hashim Othman, \\ Kamarudin Hussin
}

\begin{abstract}
The participation of students in the process of learning is one of the keys to ensure effective learning outcomes either in terms of knowledge or skill. However, teacher-centred teaching methods which have been practiced in this country after so long avert students to fully engage in the learning process especially in a classroom. Various attempts have been made by the government to emphasize student's development in term of communication, creativity and innovation through the of process learning in class. It requires school to implement student-centred teaching methods such as cooperative learning. Cooperative learning is a teaching method that requires teachers not only interacts with the students but also with other teaching aids such as audio, video and computer. Therefore, this study was conducted to identify teachers' perception on the implementation of cooperative learning in the teaching and learning process in class. 25 teachers were selected as respondents. Mixed methods were used in this study, where the instrument of questionnaires and interviews were used to collect the data. Quantitative data analysis was made using descriptive statistics of frequency, mean and percentage. While, qualitative data analysis was based on the recommendations of the Miles \& Huberman (1994). The findings showed teachers have a positive attitude toward cooperative learning and they are ready and feel confident to practice it. However, the constraints are classroom control, time and limited teaching aids
\end{abstract}

\section{Introduction}

Education plays an important role in developing countries to achieve the status of a developed country. This is because education can act a catalyst to produce creative, innovative and kwowledgable students. It can be a determinant of civilization for every country. Therefore, our goverment intervenes to improve the quality of education I n our country to ensure that we can accomplish economic development.

Nowadays, education in Malaysia can furnish students with knowledge and it can also help them develop interpersonal skills, soft skill, and generic skills [4]. We should incorporate appropriate teaching and learning methods in school curriculum in order to improve students' academic performance and enhance their soft skills such as communication skills, leadership and generic skills, simultaneously. One of the methods is cooperative learning.

According to [9] the purpose of coorperative learning is to avail students of the opportunity to think on their own. Therefore, teachers should play an imopertant role in ensuring this method can be successfully and effectively implemented in school. Also, according to the study, teachers can encourage curiosity of students by asking them questions. Thus, the students can make connections between the questions and ideas that have been generated in their mind.

In addition, Che Mansor bin Che Tom [1] stated that teachers should encourage students to think effectively in class in order to produce future generation who are able to think creatively and innovatively. Hence, educators do not only deliver their lesson, but emphasize cooperative learning in their class. Students also need to participate in the leaning process so that they can expand their mind.

Nevertheless, this method cannot be successfuly and effectively implemented if teachers have scant knowledge about how to use it. The good quality of the implementation should come from teachers who have positive perception and strong awareness about the benefits of cooperative learning. This is because teachers are the individuals who will perceive the learning outcomes as well as the one who will design the learning process including activities and methods used in class. The teaching plan in using cooperative learning methods is important. A good plan can help students realize about the importance of knowing the group and their respective functions [7] thus ensuring the effectiveness of the learning process.

\section{Purpose of Study}

The purpose of this study is to identify teachers' perception on cooperative learning.

\section{Research Methodology}

\footnotetext{
* Corresponding author: salimah@unimap.edu.my
} 
This is a pilot study in which researchers used mix method where quantitative and qualitative methods were used. Respondents involve 25 teachers of one school in Johor Bahru. It comprises the entire population of teachers in the school. While for qualitative methods, only 6 teachers from the sample were randomly selected for the interviews.

\subsection{Quantitative Method Instruments}

A set of questionnaires are used as an instrument to collect data in this study. There are 25 items that emphasize issues related to teachers' perceptions of cooperative learning which is divided into five elements, namely 1) cooperative learning attractions, 2) role of teachers, 3) teacher requirements, 4) social benefits and 5) cognitive benefits. Each element consists of 5 items. Researchers have established that respondents expressed their views on the statement of the items in the form of approval. Likert scale is used as a level of approval. The level approval indicates whether respondents have a positive or negative opinion on the statement.

\subsection{Qualitative Methods Instruments}

In order to collect data using qualitative methods, a semi-structured interview were held. Semi-structured interviews were chosen to answer the research questions about the perception of teachers in cooperative learning as well as to explore the issues of cooperative learning without limitation of opinions and not rely on the limited answer in questionnaire. A set of questions are also provide as a guidance for the researcher to ask related question.

\section{Quantitative Findings}

The aim of the study is to determine the teacher perception towards cooperative learning by examine their consent to the advantages and disadvantages of cooperative learning through the distributed questionnaires. Five elements used to assess teachers' perceptions of cooperative learning.

\subsection{Coorperative Learning attractions}

Overall, the items for this element is at the high level of agreement based upon the scale of min. Respondents agree with the items that "cooperative learning increases the level of learning for weak students (mean: 4.18)", "is a very useful teaching approach (mean: 4.12)" and a "efficient learning strategies in the classroom (min: 4:08)". However, a teacher also believes that the implementation of cooperative learning requires a high cost with a mean value of 2.92 .

\subsection{Role of Teachers}

Cooperative learning is seen by teachers as a medium for students to gain knowledge in which the teachers agreed with the statement that "with cooperative learning, students learning will not only depend by teachers alone" with a mean of 3.92. The teachers do not agree that "classes with cooperative learning activities are hard to control by the teacher" and they do not consider cooperative learning leads unfinish syllabus, with mean 3.32 and "cooperative learning give too much responsibility to the students, so the teacher does not play a role " with mean 3.16. However, most respondents agreed that "Cooperative learning takes too much time for teachers to prepare" with the smallest mean value of 2.64

\subsection{Teachers Requirements}

Items that have the highest mean is the item with the statement "I am confident to perform cooperative learning (CL) although this method requires more control than a normal teaching class methods" with a mean value of 3.92. However, for this elemen only one item has mean value at high levels while other items are at a moderate level, such as items with the statement "I feel pressured by other teachers to use CL", with mean value of 3:48 and the statement "I have a little teaching experience to perform $\mathrm{CK}$ " with a mean value of 3.24. Items with the statement "I prefer the normal teaching methods" had the smallest mean value with a mean value of 2.84 .

\subsection{Social Benefits}

Social benefits refer to how teachers see the benefits obtained by students through cooperative learning. Statement "Cooperative learning promotes confidence in face to face interaction" and "Cooperative learnings trained students to accept the opinions of others" share the same mean value and the highest with value 4:28. The other items also recorded as high mean value, "Cooperative learning can foster social interaction among students" and "Engage with the class" with mean value 4.24 and 4.08 respectively. However, there is one item with moderate mean value with the statement "Cooperative learning gives too much emphasis to the development of social skills of students" with a mean value of 2.72 .

\subsection{Cognitive Benefits}

As with the previous element, this element also shows high mean values on most items. "Cooperative Learning allows students' creativity flourish and be able to give their own ideas during the discussion" with a mean value of 4.24. The other item also at the highest level is the item with the statement "cooperative learning helps improve the understanding of students" with a mean value of 3.92 , followed by items with the statement "The concept of a subject more easily grasp by the students 
when using cooperative learning" and " cooperative learning increased student achievement " with each having a mean value of 3.88 and 3.84 . However, there is one item with moderate level mean value, $3: 48$, item with the statement "Engaging in cooperative learning disrupt academic progress"

\section{Qualitative Findings}

Results show interviewed respondents have some different answers on the implementation of cooperative learning. Overall respondents saw cooperative learning as a very effective practice in class but there are also a number of shortcomings in its implementation. Based on the findings in the interview, there are four sub-themes obtained to conclude the perceptions of respondents. The four sub-themes are 1) students involvement in cooperative learning, 2) classroom control, 3) time and 4) teaching aids.

\subsection{Student Involvement}

Student participation refers to the views of respondents about the involvement of students in the classroom when they implement cooperative learning. The response given is as below.

"..it bring more good, it builds students self esteem, provide opportunities for students to speak and get involved." (Mr C)

"Cooperative learning is good to encourage students to become more active in the classroom"

(Madam E)

"Students become more daring, more satisfied and their ideas flow faster"

(Madam D)

Based on the statements above, respondents have very positive views on how cooperative learning can increase student participation in the learning process. Furthermore, the impact of the interaction happened during the learning process boost the formation of students social skills.

\subsection{Class Control}

Although most respondents have a positive perception with cooperative learning there are also some constraints or problems that respondents perceived in cooperative learning methods, one of it is class control. Below are some of the statements of respondents about classroom control.

"To train students are difficult to control, for example if there are fast and slow learner in a group, fast learner can follow quickly than slow learner, so it become problematic to make sure all students contribute to the group" (Madam D) "it require more control over the class, need to always round the class and need to always be creative" (Madam F)

\subsection{Time}

Apart from the control class, time is also one of the constraints in the implementation of cooperative learning. Here are some of the respondents' statements about it,

"It is good to encourage students to be active, but we have time constraints, for example when there is a syllabus needs to be spent" (Madam E)

"Apart from that, we also lack of time to implement cooperative learning" (Mr B)

Based on the statements of teacher E, time constraints happens because of the need for teachers to finish the subject syllabus and teacher B said about teacher lack of times to implement cooperative learning is in terms of preparation and the time required for the activities in cooperative learning.

\subsection{Teaching Aids}

The last finding on respondents' views on cooperative learning is about teaching aids. Teaching aids refers to material and equipment that is use by respondents during the process of teaching and learning. Here are the statements of respondents about teaching aids,

"Sometimes we are lack of materials, especially if you want to use audio, because the school is only have one audio device, so if there is clash, one of the teachers need to change their teaching plan" (Mr A)

"We do have shortage of material, but the teachers here are willing to share, students also doesn't have problem to bring the materials from home as ordered" (Mr B)

Based on the given statements, the lack of teaching aids are solved with the exchange of teaching planning, purchase the material using their own cost, share the materials and ask students to bring required material from home. This element shows an implementation of cooperative learning looks like a burden to the teachers.

\section{Discussion}

Based on the five elements in quantitative data, this study show teachers have positive perceptions on cooperative learning. Positive perceptions of cooperative learning can be seen when respondents give more positive responses in the interviews and the analysis of the questionnaires in the survey.

Teachers agree that cooperative learning is one method that can turn on an attractive atmosphere in the classroom as well as to build a more positive attitude in the learning process. Cooperative learning can also form 
a student-centered teaching and learning compared to existing methods that are more teacher-centered.

However, the study also found an efficient implementation of cooperative learning requires a strong commitment from teachers. Teachers need to spend more time preparing for a lesson designing their teaching plan especially when they need to use teaching aids such as audio and video equipment. Mimi Haryani et.al., [4] also believes that the implementation of cooperative learning methods require much more time compared to traditional teaching methods, especially for teachers who are inexperienced.

Although respondents expressed the constraints in the implementation of cooperative learning, this study also proves that these constraints do not prevent teachers to implement it. Items in the teacher needs element, most of the respondents are willing to implement cooperative learning even require more control and commitment. Therefore, even though cooperative learning is not easy to implement but the teacher is still willing to do it for the positive impact on the students gained from this method.

At the same time, as a whole, more respondents agreed with the positive effects from the social and cognitive benefits derived from cooperative learning. These findings are consistent with studies Mohaffyza Mimi et. al., [6]] which concluded that cooperative learning makes students more confident to provide ideas and be actively involved in learning. In addition, cooperative learning also improves communication and increase student interaction as defined by Effendi et. al., (2006), Ibrahim et al, (2011), Zahara et. al., [8] and Mimi Haryani et. al., [4]. Each item in the element of cognitive benefit got a positive response from respondents. This proves that the respondents agreed with the cooperative learning positive impact on the cognitive development of students which can be judged from their understanding, presentation ideas, problem solving skills and academic achievement.

\section{Summary}

Overally, teachers have a positive view towards ooperative learning. Eventhough it requires a higher commitment than traditional teaching methods but all the teachers are confidence to practice cooperative learning in order to improve student achievement and make students to become a better perosn. Cooperative learning is positively viewed as effective learning practice. However, some improvement in terms of equipment availability and school management should be reviewed to make cooperative learning to be more effective.

\section{References}

1. Che Mansor bin Che Tom., Jurnal Bestari : Koleksi Guru Johor. Jabatan Pendidikan Negeri Johor. (hlmn 48), (2000)

2. Meor Ibrahim Bin Kamaruddin \& Nurul Amira Binti Ahmad, Persepsi Guru Sains Terhadap Kaedah Pembelajaran Koperatif (PK) Berdasarkan Kemahiran Sosial Pelajar Dan Minat Guru, Fakulti Pendidikan, Universiti Teknologi Malaysia, (2010)

3. Miles, M. B. dan Huberman, A. M. Qualitative data analysis. 2nd edition. Thousand Oaks, CA: Sage, (1994)

4. Mimi Haryani Hassim, Mohd. Kamaruddin Abd. Hamid, Mohd. Ariffin Abu Hassan,

5. Khairiyah Mohd. Yusof, Syed Ahmad Helmi Syed Hassan, Mazlina Esa, Enhancing Learning Through Cooperative Learning: UTM Experience. Conference on Engineering Education, Kuala Lumpur, Dec 14-15,. (2004)

6. Mimi Mohaffyza binti Mohamad, Md.Nazaruddin b. Sarji \& Masitah binti Misman, Strategi Pengajaran Pembelajaran Koperatif Dalam Tajuk Rekabentuk Dan PenghasilanProjek (Matapelajaran Kemahiran Hidup). Universiti Tun Hussein Onn Malaysia, (2008)

7. Nor Azizah Salleh, Siti Rahayah Ariffin \& Musa Daia, Penerapan Nilai Murni Melalui Pembelajaran-Kooperatif Dalam Sains. Jurnal Pendidikan 27 (2001) 47-57, (2001)

8. Zahara Aziz dan Suzela Bustam, Kesan Strategi Pembelajaran Koperatif Terhadap Pencapaian Geografi Tingkatan Satu - Topik Tumbuhan Semula Jadi dan Hidupan Liar (The Impact of Cooperative Learning Strategy on the Geography Achievement of Form One: Topics Forest and the Wild Life). Jurnal Pendidikan Malaysia. 36(1):1-10, (2011)

9. Zainudin B Abu Bakar \& Nor Hidayatul Aini Ismail, Persepsi Dan Sikap Pelajar Terhadap Pendekatan Konstruktivisme Serta Kesan Terhadap Pencapaian Dalam Mata Pelajaran Matematik . Journal Of Science And Mathematics Educational, Vol 3, Sept 2011, Pages 92-107. Universiti Teknologi Malaysia, (2011) 